\title{
LE \\ CULTE DE DIONYSOS EN ATTIQUE \\ PAR
}

\section{PAUL FOUGART}

MEMBRE DE L'INSTITUT
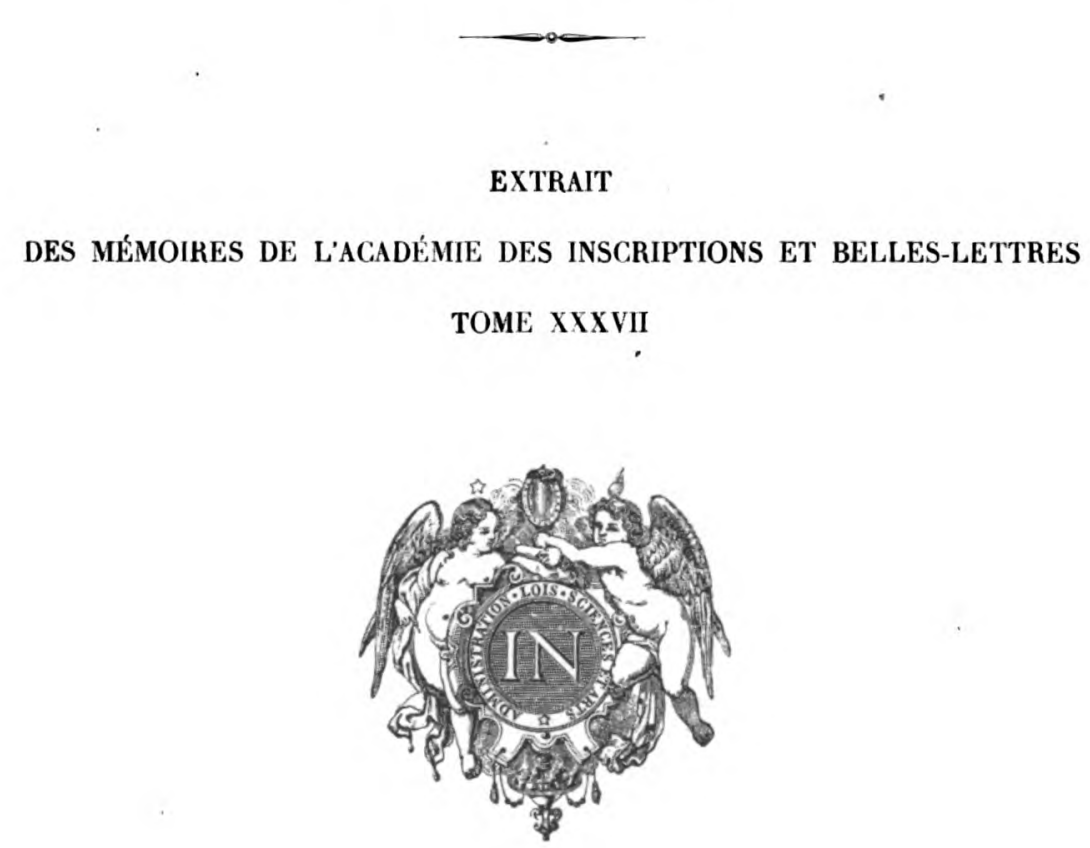

\section{PARIS}

\section{IMPRIMERIE NATIONALE}

\author{
LIBRAIRIE C. KLINCKSIECK, RUE DE LILLE, 11
}

MDCCCCIV 